\title{
Attitude of Rural Youths towards Family Farming in Dass, Bauchi State, Nigeria and the Implications for Policy
}

\author{
Abdullahi, Y.M. ${ }^{1}$ Gidado, A.S. ${ }^{2}$ and Jibril, S.A ${ }^{3}$ \\ ${ }^{1}$ Agricultural Extension and Economics Programme, National Agricultural \\ Extension and Research Liaison Services (NAERLS), Ahmadu Bello University, \\ Zaria, Nigeria. E-mail: E-mail: ymabdullahi@yahoo.com Mobile: +2348032870318 \\ ${ }^{2}$ National Open University of Nigeria, Bauchi Centre, Bauchi, Nigeria \\ ${ }^{3}$ Agricultural Economics and Extension Programme, \\ School of Agriculture and Agricultural Technology, \\ Abubakar Tafawa Balewa University, Bauchi, Nigeria
}

\begin{abstract}
This study examined the characteristics and attitude of rural youths towards family farming in Dass Local Government Area (LGA), Bauchi State, Nigeria. Multistage and systematic sampling were used to select 120 rural youths in farm families as respondents. Data was collected from them with help of structured interview schedules. Attitude was measured with a 5-point Likert type scale, while the data was analyzed using descriptive statistics. The findings show that more than half of the respondents' (56\%) were in their twenties (mode $=21-24$ yrs). Majority were males (88\%), single (51 \%), literate (99\%) and had rural background (94\%). Most of them participate in family farming (96.0\%), but in different ways (mode = labour donation), and consider farming as major occupation (71 \%). A good number (46.7 \%) had farming knowledge and experience spanning up to 10 years (mode $=5-10$ years), or more (30.8\%), which most of them (78 \%) said was learned through parents (non-formal sources). Similarly a large proportion (69\%) participates in grassroots groups and associations. It was found that about 16.0 percent of them had favourable, while $63.0 \%$ and $22.0 \%$ respectively, had a moderately favourable and unfavourable attitudes towards family farming. Their positive disposition towards farming was influenced by these demographic cultural variables or assets, in association with the natural endowments of the study area. The Dass scenario was found to be unique and amenable to sustainable agricultural and community development. A key policy implication of the situation was the need to harness these assets of the youths' towards empowering them, through appropriate strategies, to remain attracted to/and take up farming as a full time employment.
\end{abstract}

Key words: attitude, youths, family farming, Nigeria 


\section{INTRODUCTION}

Family farms all over the world can be identified by their unique socio-cultural and economic attributes. Nigeria and much of the rest of West African has a huge population of family farms which are diverse in terms of sizes, assets, market orientation, income, diversification of activities, reliance on migrants' earnings and vulnerability to risk. These farms are faced with challenges as governments in the region implement structural adjustment policies and local markets/food systems become increasingly globalised. These challenges and their intricate relationship with the overwhelming local and global economic environment under which family farms operate have rekindled a new interest in them as well as the debate on their future (Zoundi and Hitimana, 2002; Toulmin and Guèye, 2003; Brookfield, 2008).

Against the background of challenges facing family farms, farm youths like other family farm's natural and economic resources, must be preserved. They are the future generation, who will work the land in the twenty-first century. Without their involvement, agricultural development efforts will not succeed. Although youths are noted for their active involvement in family farming (Boserup, 1970; Maunder, 1978; Williams, 1978; ljere, 1989; Okoye, 1990: in Akubuilo, 2004; and Ugwoke et. al., 2005), however, there is a growing awareness of their changing attitude worldwide. The causal factors differ between countries, but an unfavorable attitude is generally evolving. In countries like Canada and USA, exogenous factors such as Government's policies/legislations e.g. the "child labour act" and farm jobrelated hazards are the most prominent causes (Sakurai, 2005; Haney, 2008). Psychological factors and economic pressure on farm families are also found to be influential factors. In some countries, many youths wonder about the viability of a career in agriculture, and yet others perceive farming as less dignifying (Russell, 1993; Malumfashi, 1999). Although the problem was noted as critical in Nigeria more than a decade ago (Olaitan 1993: in Akubuilo, 2004), efforts aimed at addressing it were far from being sufficient.

These and other factors distracting youths' attention from farming need further investigation. Therefore the relationship between the socio-economic characteristics of the youths and their attitude towards family farming needs to be exploited and understood. In this view, this research paper reports the findings of a study which determined the socio-economic characteristics affecting attitude of rural youths towards family farming in Dass Local Government Area (LGA), Bauchi State, Nigeria.

\section{METHODOLOGY}

Dass LGA lies in the Northern Guinea Savanna ecological zone of Nigeria, at about $8^{0} 40^{\prime}-9^{0} 30^{\prime}$ North, and $11^{\circ}-11^{0} 50^{\prime}$ East. Dass landscape has a varying elevation ranging between $500-1000 \mathrm{~m}$ in the low lying eastern parts to $1000-2000$ $\mathrm{m}$ above sea level in the plateau-like west (Microsoft Encarta, 2009). The LGA's land area is about 456,737 sq km (Dakup 1999, Peter 2002, Ibrahim, 2005), while the population is estimated at 86,000 (Ibrahim 2005, Bolaji 2001), which is 
accounts for only about $0.69 \%$ of that of the State. Due to the geographic advantages, annual rainfall is fairly higher than other parts of the state, ranging from 1000 to $1300 \mathrm{~mm}$. The pattern consists of 5 months of wet season and 7 months of dry season. Major land uses are: agriculture, with frequent scattered or dense shifting/cyclic cultivation (Peter, 2002).

Like other rural areas in Nigeria, the major livelihood activities include: farming, fishing, hunting, and carving (Ezeamugu, 1999; Peter, 2002). Farming practices and tools are pre-dominantly based on indigenous traditional knowledge. There is an established pattern of field crops cultivation and animal husbandry. The major crops include sorghum, rice (in commercial quantities), millet, cowpea, sweet potato, cassava, cotton, ground nut and vegetables (Peter, 2002), while the common livestock kept include cattle, sheep, goat and poultry (Dakup, 1999).

Bauchi State Agricultural Development Programme (BSADP) has zoned the area into 2 extension service blocks. Each block contains 5 cells. A cell may contain several sub-cells (or villages) depending on its population. The effects of BSADP extension services can be noticed in parts of the area, judging from farmers' acceptance of introduced crop and livestock innovations in several villages (Bolaji, 2001).

Data for the study was collected mainly from rural youths, with help of structured survey schedules. A youth was identified as a person aged between 15 to 24 years, similar to United Nation's definition (Wikipedia, 2008). The schedule contained 33 attitude statements, concepts and ideas about family farming, to which the respondents reacted by indicating agreement or disagreement. The dependent variable, attitude, was measured with help of a 5-point Likert scale (Likert, 1932), a method which is now one of the dominant in measuring people's attitudes, views and experiences (Taylor and Heath, 1996). The respondents rated the statements based on scores ranging from a minimum of 1 to a maximum of 5 , whereby Strongly Agree $=5$, Agree $=4$, Undecided $=3$, Disagree $=2$ and Strongly Disagree $=1$. The order of the ratings was reversed for negative statements in conformity with Gidado (2003), Daneji (2006), Ironkwe et al. (2006), and Tafida (2007). The independent variables: Age, Gender, Marital status, Educational status, Major occupation, Childhood background, Farming experience, Source of training and Mode of participation in family farm, were measured either directly or by devising categorical scales, as in some earlier studies (Fabiyi, 2000; Gidado, 2003; Yahaya and Olajide, 2005; Chidilum, 2006; Tafida, 2007).

Multi-stage and systematic sampling were adopted. Initially, 6 of the 10 cells in Dass LGA were selected for the study. From each cell, 2 villages were surveyed. In each village, every other $5^{\text {th }}$ household was chosen, from which one youth was identified and interviewed as the key respondent for the study. This gave a sum of 20 respondents per cell and sample size of 120 respondents. Houses with no youth were discarded and the next $5^{\text {th }}$ household was used as replacement.

To evaluate the socio-economic characteristics of the respondents, descriptive statistical method like frequency counts, mean, standard deviation, mode and tables were used, similar to Fabiyi, 2000; Gidado, 2003 and Tafida, 2007. Respondents' attitude towards family farming was determined based on their 
mean score and the standard deviation, as earlier used by Gidado (2003), Tafida (2007) and Uddin et al (2008).

Based on the standard deviation (SD) and the Mean $\left(x^{-}\right)$, a 3-point scale similar was used to categorize the respondents' attitude as follows: respondents with favourable attitude are those whose total scores were less than the mean minus the standard deviation (scores <(Mean -SD). Respondents with moderately favourable attitude are those whose scores range from the mean minus the standard deviation to the mean plus the standard deviation (scores from (Mean$\mathrm{SD}$ ) to (Mean+SD). Finally, respondents with unfavourable attitude were those whose total scores were greater than the sum of the mean and standard deviation (scores $>$ (Mean+SD).

\section{RESULTS AND DISCUSSION}

\section{Socio-economic characteristics of the respondents}

The socio-economic characteristics of the respondents examined were: age, gender, marital status, major occupation, education, childhood background, sources of farm training and mode of participation in the family farm (Table 1). The finding provided interesting insights into the respondents socio-economic backgrounds. More than half of them (56\%) were young adults in their twenties (mode $=21-24 \mathrm{yrs}$ ). A major asset of the youth is their age. Age and dynamism considerably contribute to many of the qualities associated with young people; such as their active involvement in community development, higher social propensity, faster reaction time, and proneness to innovation (Adesope, 2007). It therefore becomes necessary to harness and exploit these assets in youths' in time and in the right way.

Majority of the respondents were males (88\%), single (51\%), and literate (99\%). Nearly all of them had rural up-bringing (94\%), participate in family farming (96.0 $\%)$, in different ways (mode = labour donation), and consider farming as a major occupation (71 percent). A good number of them (46.7\%) had farming experience spanning up to 10 years (mode $=5-10$ years), or more $(30.8 \%$ ), and as is common in family farms, acquired such experiences/skills through informal sources (78\%), e.g. parents, relations and neighbors'.

As youths, the role and importance of the respondents in national development cannot be overemphasized. Here in Nigeria, past Government-sponsored programmes aimed at socio-economic empowerment of the youth attest to this fact (Agumagu et al., 2006). However, a key policy implication of the current Dass scenario is the need for harnessing these assets (demographic cultural characteristics) of the youths towards sustainable agricultural and community development. There is need to synergize these positive assets of the respondents with the study area's natural/environmental endowments (such as fairly high annual rainfall, moderate temperatures, fertile soils, etc) in order to improve family agriculture, household food security and socio-economic well being. The youth can serve as an important entry point in the process of achieving this goal at the family farm level. 
TABLE 1: The Respondents Socio-economic Characteristics ( $n=120)$

\begin{tabular}{|c|c|c|}
\hline Variable & Frequency & Percentage \\
\hline \multicolumn{3}{|l|}{ Age range (yrs): } \\
\hline $\begin{array}{l}15-17 \\
18-20\end{array}$ & $\begin{array}{l}12 \\
35\end{array}$ & $\begin{array}{l}10 \\
29.2\end{array}$ \\
\hline \multirow{2}{*}{\multicolumn{3}{|c|}{ Gender: }} \\
\hline & & \\
\hline Male & 105 & 87.5 \\
\hline Female & 14 & 11.7 \\
\hline \multicolumn{3}{|l|}{ Marital status: } \\
\hline Married & 51 & 42.5 \\
\hline Single & 61 & 50.8 \\
\hline Divorced & 2 & 1.7 \\
\hline Widowed & 2 & 1.7 \\
\hline \multicolumn{3}{|l|}{ Educational Attainment: } \\
\hline Quranic/Biblical & 17 & 14.2 \\
\hline Adult Lit. & 8 & 6.7 \\
\hline Primary & 21 & 17.5 \\
\hline Junior Sec. Sch. & 23 & 19.2 \\
\hline Full Sec.Sch & 43 & 35.8 \\
\hline Dip/NCE & 7 & 5.8 \\
\hline None & 1 & 0.8 \\
\hline \multicolumn{3}{|l|}{ Major Occupation: } \\
\hline Farmer & 85 & 70.8 \\
\hline Pastoralist & 9 & 7.5 \\
\hline Trader & 7 & 5.8 \\
\hline Comm. M/Cycle Operator & 5 & 4.2 \\
\hline Carpenter & 2 & 1.7 \\
\hline Tailor & 4 & 3.3 \\
\hline Labourer & 1 & 0.8 \\
\hline None & 1 & 0.8 \\
\hline Others & 6 & 5 \\
\hline \multicolumn{3}{|l|}{ Childhood Background: } \\
\hline Rural & 113 & 94.2 \\
\hline Urban & 5 & 4.2 \\
\hline \multicolumn{3}{|l|}{ Farming experience (yrs): } \\
\hline None & 5 & 4.2 \\
\hline$<5$ & 21 & 17.5 \\
\hline 5 to 10 & 37 & 30.8 \\
\hline \multicolumn{3}{|l|}{ Source of farm training: } \\
\hline Formal & 25 & 20.8 \\
\hline Informal & 94 & 78.3 \\
\hline \multicolumn{3}{|l|}{ Participation in farm work: } \\
\hline Supervision & 5 & 4.2 \\
\hline Advise & 13 & 10.8 \\
\hline Labour & 87 & 51.88 \\
\hline Cash & 8 & 6.7 \\
\hline Not involved & 5 & 4.2 \\
\hline
\end{tabular}

Source: Survey Data, 2009 


\section{Attitude of the Respondents towards Family Farming}

\section{Attitude categorization}

Analysis of the respondents attitude illustrates that as many as $78.33 \%$ can be considered as positively inclined towards family farming (Table 4.2), because they had favourable $(15.83 \%)$ and moderate $(62.5 \%)$ attitudes. Only about one fifth (21.67 percent) had unfavourable attitude towards family farming. This result contradicts some earlier research findings which reported negative trends elsewhere (Russell, 1993; Hargesheimer, 1998; Malumfashi, 1999; Ekujere, 2001; Sakurai, 2005; and Haney, 2008).

This indicates that a different scenario prevails in the study area. The trend is not surprising in view of the respondents' dynamic socio-economic and cultural characteristics (Table 1), and their likely effects on their attitude towards family farming. This is yet another asset of the youths in the study area. One of the implications for policy is the need for provision of technical and institutional support the youths. As future farmers, these youths deserve such support, in order to motivate and empower them to remain in farming. In this regards a well packaged agricultural development support programme, specifically designed for youths in family farms is desirable. Such a programme can make substantial contributions towards harnessing the assets of the youth for achieving community sustainability and food security.

TABLE 2: Categories of the respondents' attitude

\begin{tabular}{lllll}
\hline Attitude & Freq. & Percent & Mean & Std. Dev \\
\hline Favourable & 19 & 15.83 & & \\
Moderate & 75 & 62.5 & 114.4 & 9.53 \\
Unfavourable & 26 & 21.67 & & \\
\hline Totals & $\mathbf{1 2 0}$ & $\mathbf{1 0 0}$ & & \\
& & & & \\
\hline
\end{tabular}

Source: Survey Data, 2009.

\section{Implications for Policy}

In the light of the findings of this study, the following are enumerated as some of the implications for policy:

A key implication is the need for dynamism, positive attitude towards family agriculture and other assets of the youths to be harnessed, mobilized and empowered through technical and Institutional support. Public institutions like 
Agricultural Extension and Rural development Organizations, Local Governments Authorities, Universities of Agriculture, Polytechnics and Colleges of Agriculture, and National Agricultural Research and Development Institutions; must make the right kind of investment in the study area and on the youth, so as to support and encourage them to develop their agricultural potentials.

Supporting and empowering the youths will enhance their access to agricultural innovations, extension services, training, inputs, credit and markets (both regional and international) and motivate them to remain in farming, and achieve sufficient increase in productivity, income and living standard.

Rural youths in the study area require direct and continuous support and encouragement to sustain their level of interest in farming. As future farmers of the nation, they need to be encouraged to go into full-time agri-ventures. This can be achieved through increased training opportunities, participation in agricultural extension activities and programmes, access to agricultural innovations and other forms of support.

\section{CONCLUSION AND RECOMMENDATIONS}

This study which examined the attitude of rural youths towards family farming in Dass Local Government Area of Bauchi State, Nigeria, concludes that rural youths in the study area have outstanding socio-economic abilities (or socio-economic assets), where-in lies the primary source of inspiration for their positive disposition towards family farming. The positive inclination may not be unconnected with particularly the fact that most of them are in their dynamic age of 21-24 years, highly literate, see farming as a major source of livelihood, and keenly participate in the family farm. These and other attributes or assets possessed by the respondents are the factors that profoundly influenced their positive inclination towards family farming. Contrary to the negative scenario reported in certain areas (Russell, 1993; Hargesheimer, 1998; Malumfashi, 1999; and Haney, 2008), the respondents' positive mindset towards the family farm is a source of strength. It further suggests that rural youths in the study area can easily be supported and motivated to remain in and take farming up as a career.

Those that wish to study agriculture in higher institutions should be encouraged through award of scholarships, and be assisted financially to take up farming as a profession after graduation. In general rural youths in family farms require technical support and an enabling environment in the form of increased access to agricultural research and extension services, entrepreneurship skills, inputs, credit and markets (both local, regional and international). Finally there is need for a deeper and sounder research on this problem to explore it on a wider scale, its nature in entire Bauchi State for example. 


\section{REFERENCES}

Adesope, OM (2007). Agricultural youth organizations: introductory concepts. Second edition, University of Port Harcourt Press, Port Harcourt, Nigeria, pp.1-3.

Adesope OM, Agumagu AC, Nwankwo C (2007). Importance of youths in community development: perspectives fo agricultural extension. In: Agumagu, A.C. et al (eds) Contemporary issues in Agricultural extension and development studies. Series one. Port Harcourt: Molsyfem United Services.

Agumagu AC, Adesope OM, Matthews-Njoku EC (2006). Attitude of youth corpers towards the community development service of NYSC in Nigeria. J. Agric. Soc. Res., 6 (1): 70-75

Akubuilo, C.J.K. (2004). Adoption of agricultural innovations by children-inagriculture programme (CIAP) members in Enugu State of Nigeria. African J. Of Farm Child and Youth Dev. 31.

Bolaji, L. O. (2001). Socio-economic characteristics of small scale agriculture - an appraisal of farmers in Dass Local Government Area. A Bachelor of Agricultural Technology research project (unpublished), Agricultural Economics and Extension programme, ATBU Bauchi, Nigeria.

Brookfield, H. (2008). Family farms are still around-time to invert the old agrarian question. Geography Compass 2:(1), 108-126

Chidilum, E. (2006). Motivational factors of job performance of Agricultural Extension Agents in Bauchi State Agricultural Development Programme - a case study of Western zone. A Bachelor of Agricultural Technology research project (unpublished), Agricultural Economics and Extension programme, ATBU Bauchi, Nigeria.

Dakup, E.Y. (1999). Economic analysis of intra-season rice marking in Bauchi State - a case study of Dass Local Government Area. A Bachelor of Agricultural Technology research project (unpublished), Agricultural Economics and Extension programme, ATBU Bauchi, Nigeria.

Daneji, M. I. (2006). Multivariate analysis of women participation in agricultural activities in Bauchi State. PhD Thesis in Agricultural Extension (Unpublished), Agricultural Economics and Extension Programme, School of Agriculture and Agricultural Technology, Abubakar Tafawa Balewa University, Bauchi, Nigeria.

Ekujere, C. C. (2001). Attitude of secondary school students towards agriculture a case study of selected secondary schools in Gombe metropolis. A Bachelor of Agricultural Technology research project (unpublished), Agricultural Economics and Extension programme, ATBU Bauchi, Nigeria, Pp46. 
Ezeamugu, J.C. (1999). Economics of selected aspects of rice production and marketing in Dass LGA Bauchi State. A Bachelor of Agricultural Technology research project (unpublished), Agricultural Economics and Extension programme, ATBU Bauchi, Nigeria.

Fabiyi, E. F. (2000). The effects of agricultural extension services on technology ransfer for rice production in Bauchi Local Government Area, Bauchi State, Nigeria. M.Sc. Thesis in Agricultural Extension (Unpublished). Agricultural Economics and Extension Programme, School of Agriculture and Agricultural Technology, Abubakar Tafawa Balewa University, Bauchi, Nigeria.

Gidado, S.A. (2003). Multivariate determinants of farmers and extension worker attitude towards animal traction technology in Bauchi State. PhD Thesis in Agricultural Extension (Unpublished), Agricultural Economics and Extension Programme, School of Agriculture and Agricultural Technology, Abubakar Tafawa Balewa University, Bauchi, Nigeria.

Haney, S. (2008). Encourage farm youth to attend agricultural schools, grainnews.ca, January $28^{\text {th }}$ p25 URL: http://www.allacademic.com/meta/p22950 index.html. Accessed March 2009

Hargesheimer, Ken (1998). Youth and Urban Agriculture. City Farmer, February, URL: http://www.cityfarmer.org/donate.html\#donate

Ironkwe, A.G., Ekwe, K.C., and Mbanaso, E.O. (2006). Participation of extension agents in Research-Extension-Farmer-Input-Linkage-System (REFILS) activities in Abia State. Nigerian Journal of Agricultural Extension, 9:109115

Likert, R (1932). A Technique for the Measurement of Attitudes. Archives of Psychology; No.140

Malumfashi, S H (1999). Interest of youth in agriculture-a case study of students of agriculture, ATBU Bauchi. A Bachelor of Agricultural Technology research project (unpublished), Agricultural Economics and Extension programme, ATBU Bauchi, Nigeria, 47Pp.

Peter, D. (2002). Economics of selected aspects of vegetable crops under dry season production - a cases study of Dass Local Government Area. A Bachelor of Agricultural Technology research project (unpublished), Agricultural Economics and Extension programme, ATBU Bauchi, Nigeria, 46Pp.

Russell, E. B. (1993). Attracting Youth to Agriculture, Journal of Extension, 13:4. URL: http://www.joe.org/joe/1993winter/a2.html.

Sakurai, R. (2005, Aug) "Adolescent Employment in Agriculture in the U.S.: Does It Impair Students? Academic Achievement?" Paper presented at the annual meeting of the American Sociological Association, Philadelphia, USA. URL: doi:10.1111/j.1749-8198.2007.00078.x 
Tafida, I. (2007). Evaluation of farmers attitude and participation in National Special Programme for food Security (NSPFS): case study of Warawa Local Government Area (LGA), Kano State, Nigeria. M.Sc. Thesis in Agricultural Extension (Unpublished). Agricultural Economics and Extension Programme, School of Agriculture and Agricultural Technology, Abubakar Tafawa Balewa University, Bauchi, Nigeria.

Taylor, B and A. Heath (1996). The use of double-sided items in scale construction. Working Paper no. 37, Centre for Research into Elections and Social Trends: Abstract available online at URL: http://www.crest.ox.ac.uk/p37.htm [11.01.03]. Accessed June 2009.

Toulmin, C. and Guèye, B. (2003). Transformation in West African Agricultures and the role of family farms. Sahel and West Africa Club (SWAC/OECD), SAH/D (2003)541, Paris, France, 144 p.

Uddin, M.E., Rashid, M. U. and Akanda, M. G. R. (2008). Attitude of Coastal Rural Youth towards Some Selected Modern Agricultural Technologies J. Agric Rural Dev, 6(1\&2), 133-138

Ugwoke FO, Adesope OM, Ibe FC (2005). Youths participation in farming activities in rural areas of Imo State, Nigeria. Implications for extension. J. Agric. Ext. 8: $136-142$.

Wikipedia (2008). Attitude (Psychology).Available free online information. URL: http://en.wikipedia.org/wiki/Attitude (psychology)\#column-one, Page Last Modified 18-01-2008. Accessed 2008.

Yahaya, M. K. and Olajide, A. O. (2005). Assessment of impact of Nigeria Agricultural and Cooperative Bank (NACB) credit facilities on small scale farmers in Ibarapa East Local Government Area, Oyo State. Journal of Agricultural Extension, vol. 8, pp16-21

Zoundi, J. S. and Hitimana, L. (2002). The Challenges facing West African Family Farms in Accessing Agricultural Innovations: Institutional and Political Implications. Sahel and West Africa Club (SWAC/OECD), 2, rue AndréPascal, 75775 Paris, France. 